\title{
Correction to: When Conscience Wavers. Some Reflections on the Normalization of Euthanasia in Belgium
}

\author{
Willem Lemmens
}

\section{Correction to: T. Devos (ed.), Euthanasia: Searching for the Full Story, https://doi.org/10.1007/978-3-030-56795-8}

\section{Corrections:}

The original version of the chapter was inadvertently published with incorrect number in the text. The number should read as follow:

\section{"1 Belgian in 50"}

The below paragraph has been added to the first footnote in the chapter.

Moreover, a previous study mentions that the actual number of euthanasia cases in Belgium might be considerably higher than the cases reported to the official Belgian control commission for euthanasia. Despite the fact that the law requires an official report to be submitted to this commission, the study notices that in a sample period of 6 months in 2007 "approximately half (549/1040 (52.8\%, 95\% CI 43.9\% to $60.5 \%)$ ) of all estimated cases of euthanasia were reported to the Federal Control and Evaluation Committee". Cf.Smets T, Bilsen J, Cohen J, Rurup ML, Mortier F, Deliens L. Reporting of euthanasia in medical practice in Flanders, Belgium: Cross sectional analysis of reported and unreported cases. BMJ. 2010;341(7777):819. https://doi.org/10.1136/bmj.c5174.

The updated online version of the chapter can be found at https://doi.org/10.1007/978-3-03056795-8_3 
Open Access This chapter is licensed under the terms of the Creative Commons Attribution 4.0 International License (http://creativecommons.org/licenses/by/4.0/), which permits use, sharing, adaptation, distribution and reproduction in any medium or format, as long as you give appropriate credit to the original author(s) and the source, provide a link to the Creative Commons license and indicate if changes were made.

The images or other third party material in this chapter are included in the chapter's Creative Commons license, unless indicated otherwise in a credit line to the material. If material is not included in the chapter's Creative Commons license and your intended use is not permitted by statutory regulation or exceeds the permitted use, you will need to obtain permission directly from the copyright holder. 